\title{
Information and Communication Technology in Patient Education and Support for People With Schizophrenia
}

\author{
Maritta Välimäki*,,2, Heli Hätönen ${ }^{1}$, Mari Lahti ${ }^{1}$, Lauri Kuosmanen ${ }^{1}$, and Clive E. Adams ${ }^{3}$ \\ ${ }^{1}$ Department of Nursing Science, University of Turku, Turku, Finland; ${ }^{2}$ Southwest Hospital District, Turku, Finland; ${ }^{3}$ Cochrane \\ Schizophrenia Group, The University of Nottingham, Nottingham, UK \\ *To whom correspondence should be addressed; Department of Nursing Science, University of Turku, Turku, Finland; tel: +358-2-333-8495, \\ fax: +358-2-333-8400, e-mail: mava@utu.fi
}

Key words: schizophrenia/information technology/ patient education

\section{Background}

Poor compliance with treatment often means that many people with schizophrenia or other severe mental illness relapse and may need frequent and repeated hospitalization. Information and communication technology (ICT) is increasingly being used to deliver information, treatment or both for people with severe mental disorders.

\section{Objectives}

To evaluate the effects of psychoeducational interventions using ICT as a means of educating and supporting people with schizophrenia or related psychosis.

\section{Search Methods}

We searched the Cochrane Schizophrenia Group Trials Register (2008, 2009, and September 2010), inspected references of identified studies for further trials, and contacted authors of trials for additional information.

\section{Selection Criteria}

All clinical randomized controlled trials (RCTs) comparing ICT as a psychoeducational and supportive tool with any other type of psychoeducation and supportive intervention or standard care.

\section{Data Collection and Analysis}

We selected trials and extracted data independently. For homogenous dichotomous data we calculated fixed-effect risk ratios (RR) with $95 \%$ confidence intervals (CI). For continuous data, we calculated mean differences (MD). We assessed risk of bias using the criteria described in the Cochrane Handbook for Systematic Reviews of Interventions.

\section{Results}

We included 6 trials with a total of 1063 participants. We found no significant differences in the primary outcomes (patient compliance and global state) between psychoeducational interventions using ICT and standard care.

Technology-mediated psychoeducation improved mental state in the short term $(n=84,1 \mathrm{RCT}, \mathrm{RR} 0.75 \mathrm{CI}$ $0.56-1.00 ; n=30,1 \mathrm{RCT}, \mathrm{MD}-0.51 \mathrm{CI}-0.90-0.12$ ) but not global state $(n=84,1$ RCT, RR 1.07 CI $0.82-1.42)$. Knowledge and insight were not effected $(n=84,1 \mathrm{RCT}$, RR 0.89 CI $0.68-1.15$; $n=84,1$ RCT, RR 0.77 CI $0.58-$ 1.03). People allocated to technology-mediated psychoeducation perceived that they received more social support than people allocated to the standard care group $(n=30$, 1 RCT, MD 0.42 CI 0.04-0.80). When technology-mediated psychoeducation was used as an adjunct to standard care, it did not improve general compliance in the short term $(n=291,3 \mathrm{RCTs}$, RR for leaving the study early 0.81 CI $0.55-1.19)$ or in the long term $(n=434,2$ RCTs, RR for leaving the study early 0.70 CI $0.39-1.25$, figure 1 ). However, it did improve compliance with medication in the long term ( $n=71,1$ RCT, RR 0.45 CI 0.27-0.77). Adding technology-mediated psychoeducation on top of standard care did not clearly improve either general mental state, negative or positive symptoms, global state, level of knowledge or quality of life (table 1). However, the results were not consistent regarding level of knowledge and satisfaction with treatment. When technology-mediated psychoeducation plus standard care was compared 


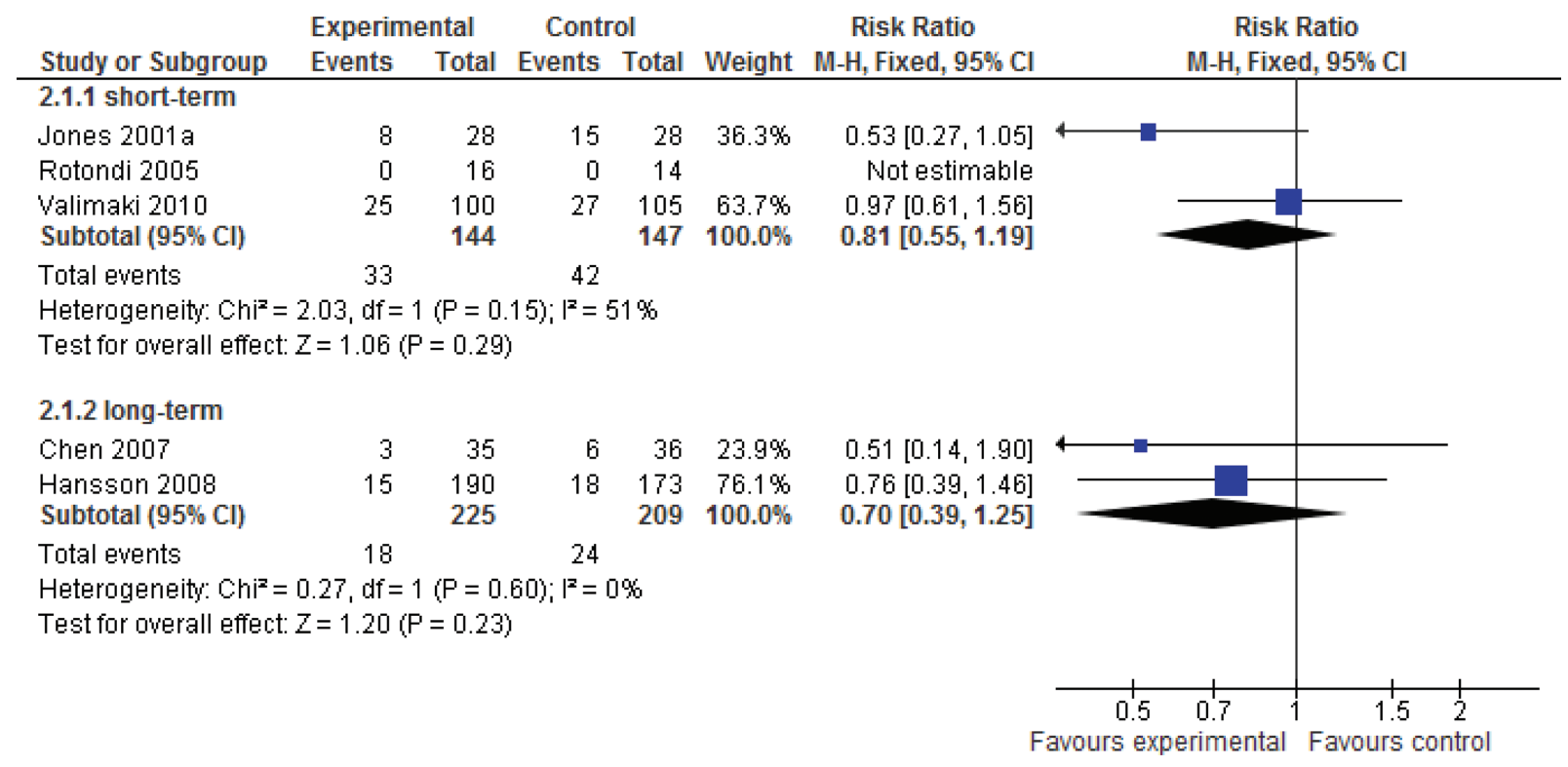

Fig. 1. Compliance: general—-leaving the study early_any reason.

Table 1. Technology-Mediated Psychoeducation + Standard Care Intervention Compared With Standard Care Intervention for People With Schizophrenia

\begin{tabular}{|c|c|c|c|c|c|}
\hline \multirow[b]{3}{*}{ Outcomes } & \multicolumn{2}{|c|}{ Illustrative Omparative Risks* $(95 \%$ CI) } & \multirow[b]{3}{*}{$\begin{array}{l}\text { Relative Effect } \\
(95 \% \mathrm{CI})\end{array}$} & \multirow[b]{3}{*}{$\begin{array}{l}\text { No. of } \\
\text { Participants } \\
\text { (Studies) }\end{array}$} & \multirow[b]{3}{*}{$\begin{array}{l}\text { Quality of the } \\
\text { Evidence (GRADE) }\end{array}$} \\
\hline & Assumed Risk & Corresponding Risk & & & \\
\hline & $\begin{array}{l}\text { Standard Care } \\
\text { Intervention }\end{array}$ & $\begin{array}{l}\text { Technology-Mediated } \\
\text { Psychoeducation }+ \\
\text { Standard Care } \\
\text { Intervention }\end{array}$ & & & \\
\hline \multirow{2}{*}{$\begin{array}{l}\text { Compliance/ } \\
\text { satisfaction: } \\
\text { medication-not } \\
\text { compliant-long-term } \\
\text { follow-up: } 52 \mathrm{wk}\end{array}$} & \multirow{2}{*}{$\begin{array}{l}\text { Moderate }^{\mathrm{a}} \\
700 \text { per } 1000\end{array}$} & & \multirow{2}{*}{$\begin{array}{l}\text { RR } 0.45 \\
\quad(0.27-0.77)\end{array}$} & \multirow[t]{2}{*}{71 (1 study) } & \multirow[t]{2}{*}{$\oplus \ominus \ominus \ominus$ very low ${ }^{b, c, d}$} \\
\hline & & $\begin{array}{r}315 \text { per } 1000 \\
(189-539)\end{array}$ & & & \\
\hline \multirow{2}{*}{$\begin{array}{l}\text { Mental state: not } \\
\text { improved-short-term } \\
\text { BPRS follow-up: } 12 \\
\text { wk }\end{array}$} & Moderate $^{a}$ & \multirow[b]{2}{*}{$\begin{array}{c}602 \text { per } 1000 \\
\quad(441-833)\end{array}$} & \multirow{2}{*}{$\begin{array}{l}\text { RR } 0.86 \\
\quad(0.63-1.19)\end{array}$} & \multirow[t]{2}{*}{56 (1 study) } & \multirow[t]{2}{*}{$\oplus \oplus \ominus \ominus$ low $^{\mathrm{e}, \mathrm{f}, \mathrm{g}}$} \\
\hline & 700 per 1000 & & & & \\
\hline \multirow{2}{*}{$\begin{array}{l}\text { Global state: not } \\
\text { improved-short-term } \\
\text { GAF follow-up: } 12 \mathrm{wk}\end{array}$} & Moderate $^{a}$ & & \multirow{2}{*}{$\begin{array}{l}\text { RR } 1.15 \\
\quad(0.86-1.54)\end{array}$} & \multirow[t]{2}{*}{56 (1 study) } & \multirow[t]{2}{*}{$\oplus \oplus \ominus \ominus$ low $^{\mathrm{e}, \mathrm{g}}$} \\
\hline & 700 per 1000 & $\begin{array}{l}805 \text { per } 1000 \\
(602-1000)\end{array}$ & & & \\
\hline \multirow{2}{*}{$\begin{array}{l}\text { Knowledge/insight: } \\
\text { not improved-ITAQ } \\
\text { follow-up: } 12 \mathrm{wk}\end{array}$} & Moderate $^{a}$ & & \multirow{2}{*}{$\begin{array}{l}\text { RR } 1 \\
\quad(0.76-1.31)\end{array}$} & \multirow[t]{2}{*}{56 (1 study) } & \multirow[t]{2}{*}{$\oplus \oplus \ominus \ominus \mathrm{low}^{\mathrm{e}, \mathrm{g}}$} \\
\hline & 700 per 1000 & $\begin{array}{c}700 \text { per } 1000 \\
(532-917)\end{array}$ & & & \\
\hline Quality of life & & & Not estimable & $0(0)$ & $\begin{array}{l}\text { No trial reported this } \\
\text { outcome. }\end{array}$ \\
\hline Needs & & & Not estimable & $0(0)$ & $\begin{array}{l}\text { No trial reported this } \\
\text { outcome. }\end{array}$ \\
\hline
\end{tabular}


Table 1. Continued

\begin{tabular}{|c|c|c|c|c|c|}
\hline \multirow[b]{3}{*}{ Outcomes } & \multicolumn{2}{|c|}{ Illustrative Omparative Risks* (95\% CI) } & \multirow[b]{3}{*}{$\begin{array}{l}\text { Relative Effect } \\
(95 \% \mathrm{CI})\end{array}$} & \multirow[b]{3}{*}{$\begin{array}{l}\text { No. of } \\
\text { Participants } \\
\text { (Studies) }\end{array}$} & \multirow[b]{3}{*}{$\begin{array}{l}\text { Quality of the } \\
\text { Evidence (GRADE) }\end{array}$} \\
\hline & Assumed Risk & Corresponding Risk & & & \\
\hline & $\begin{array}{l}\text { Standard Care } \\
\text { Intervention }\end{array}$ & $\begin{array}{l}\text { Technology-Mediated } \\
\text { Psychoeducation }+ \\
\text { Standard Care } \\
\text { Intervention }\end{array}$ & & & \\
\hline Social support & & & Not estimable & $0(0)$ & $\begin{array}{l}\text { No trial reported this } \\
\text { outcome. }\end{array}$ \\
\hline
\end{tabular}

Note: BPRS: Brief Psychiatric Rating Scale; CI: Confidence interval; GAF: Global Assessment of Functioning; RR: Risk ratio. *The basis for the assumed risk (eg, the median control group risk across studies) is provided in footnotes. The corresponding risk (and its 95\% CI) is based on the assumed risk in the comparison group and the relative effect of the intervention (and its 95\% CI).

GRADE Working Group grades of evidence: High quality: Further research is very unlikely to change our confidence in the estimate of effect. Moderate quality: Further research is likely to have an important impact on our confidence in the estimate of effect and may change the estimate. Low quality: Further research is very likely to have an important impact on our confidence in the estimate of effect and is likely to change the estimate. Very low quality: We are very uncertain about the estimate.

${ }^{a}$ Moderate control group risk approximates that in trial control group.

bimitation in design: rated "serious" — randomization not well described_- "Randomized participants matched (age, gender, length of

illness, type of schizophrenia)" - no further details.

"Imprecision: rated as "serious" - small sample size.

dPublication bias: rated as "likely" - small single trial.

"Limitation in design: rated "serious"-randomization not described.

${ }^{\mathrm{f}}$ Assumed those who discontinued would not change if had remained in study.

gPublication bias: rated "likely"_outcome data incomplete.

with patient education not using technology the only outcome reported was satisfaction with treatment. There were no differences between groups.

\section{Authors' Conclusion}

Using ICT to deliver psychoeducational interventions has no clear effects compared with standard care, other methods of delivery and outcomes, and studies were few and underpowered. ICT remains a promising method of delivering psychoeducation; the equivocal findings of this review should not postpone high-quality research in this area. For full details, please see Välimäki et al. 2012. ${ }^{1}$

\section{Reference}

1. Välimäki M, Hätönen H, Lahti M, Kuosmanen L, Adams CE. Information and communication technology in patient education and support for people with schizophrenia. Cochrane Database of Systematic Reviews. 2012; 10:CD007198. doi:10. 1002/14651858.CD007198.pub2. 